\title{
Effect of substituting soybean meal and canola cake with dried distillers grains with solubles at 2 dietary crude protein levels on feed intake, milk production, and milk quality in dairy cows
}

\author{
C. Gaillard, ${ }^{*}$ M. T. Sørensen, ${ }^{*}$ M. Vestergaard, ${ }^{*}$ M. R. Weisbjerg, ${ }^{*}$ A. Basar, ${ }^{*}$ M. K. Larsen,† H. Martinussen,ł \\ U. Kidmose,§ and J. Sehested*1 \\ *Department of Animal Science, and \\ †Department of Food Science, Aarhus University, Foulum, Blichers Allé 20, 8830 Tjele, Denmark \\ ‡SEGES, Agro Food Park 15, 8200 Aarhus N, Denmark \\ §Department of Food Science, Aarhus University, Kirstinebjergvej 10, 5792 Aarslev, Denmark
}

\begin{abstract}
Dried distillers grain with solubles (DDGS) is an alternative source of feed protein for dairy cows. Previous studies found that DDGS, based on grains other than corn, can substitute for soybean meal and canola cake as a dietary protein source without reducing milk production or quality. As societal concerns exist, and in many areas strict regulation, regarding nitrogen excretion from dairy cows, the dairy industry has focused on reducing dietary protein level and nitrogen excretion. In the present study, we investigated the use of DDGS as a protein source, at a marginally low dietary crude protein (CP) levels, in a grass-clover and corn silagebased ration. The experiment involved 24 Holstein cows and 2 protein sources (DDGS or soybean-canola mixture) fed at 2 levels of CP (14 or $16 \%$ ) in a $4 \times$ 4 Latin square design. The aim of this study was to evaluate the effect of both protein source and protein level on feed intake, milk yield, and milk quality. The results indicated that feed intake, milk yield, and protein in milk increased when the protein level in the ration was $16 \% \mathrm{CP}$ compared with $14 \%$. We found no effect of substituting the soybean-canola mixture with DDGS. Moreover, no sensory problems were observed when comparing fresh milk with stored milk, and milk taste was unaffected by DDGS. Milk from cows fed DDGS had a slightly higher content of linoleic acid and conjugated linoleic acid (CLA 9-11), and lower content of $\mathrm{C} 11$ to $\mathrm{C} 17$ fatty acids than cows fed diets with the soybean-canola mixture. Cows fed the diets with $16 \%$ CP produced milk with higher oleic acids and lower palmitic acid content than cows fed $14 \% \mathrm{CP}$ diets. To conclude, DDGS can substitute for a soybean-canola mixture without affecting feed intake, milk yield and
\end{abstract}

Received February 13, 2017.

Accepted July 3, 2017.

${ }^{1}$ Corresponding author: jakob.sehested@anis.au.dk quality, or sensory quality. Under the conditions of this experiment, feeding $16 \% \mathrm{CP}$ compared with $14 \% \mathrm{CP}$ in the ration can increase feed intake and milk production. Key words: coproduct, dried distillers grains with solubles, protein level, dairy cow

\section{INTRODUCTION}

Dried distillers grains with solubles (DDGS) has shown to be an alternative source of feed protein for dairy cows (Anderson et al., 2006; Janicek et al., 2008; Mjoun et al., 2010; Yildiz and Todorov, 2014). Corn and other grains (i.e., barley and wheat) are the predominant substrates used in the ethanol industry, from which DDGS is a co-product rich in protein and fiber and already widely used in dairy cow feeding (Anderson et al., 2006; Janicek et al., 2008; Chrenkova et al., 2012). Recently, it was shown that DDGS, based on a mixture of triticale, wheat, and barley, can substitute for soybean meal and canola cake as a dietary protein source without reducing milk production or milk quality when fed at $16.5 \%$ dietary CP (Gaillard et al., 2017). It is well known that both DMI and milk yield respond to dietary $\mathrm{CP}$ level in the range of 15 to $17 \%$ (Broderick, 2003). As societal concerns exist, and in many areas strict regulations, regarding nitrogen excretion from dairy cows, the dairy industry has focused on reducing dietary protein level and nitrogen excretion (Hynes et al., 2016a,b; Ouellet and Chiquette, 2016). Therefore, it is relevant to study whether DDGS, based on grains other than corn, can also substitute for standard protein sources such as soybean meal and canola cake at marginally low dietary CP levels. Broderick (2003) reported a linear increase in DMI when dietary CP was increased from 15.1 to 16.7 and $18.3 \%$; however, milk yield only increased with the first $\mathrm{CP}$ increment, from 33.0 to $34.1 \mathrm{~kg} / \mathrm{d}$, with no further change at $18.3 \%$ $\mathrm{CP}$, resulting in lower feed efficiency $(\mathrm{kg}$ of milk $/ \mathrm{kg}$ of DMI) at the highest CP level. Dried distillers grains 
with solubles have a lower concentration of potentially limiting AA, such as Lys, compared with traditional protein sources, such as soybean meal and canola cake (Oba et al., 2010), and there is also variation in Lys and protein content among different batches of DDGS (Belyea et al., 2010; De Boever et al., 2014). These differences in quality may negatively influence the value of DDGS as a protein feed at marginally low dietary CP levels. The efficiency of protein utilization will depend on the AA balance in the undegraded protein portion of the diet. Lys is the first limiting AA in a corn-based by-product (Nichols et al., 1998; Liu, 2008) and is susceptible to excessive heat during the preparation of DDGS (Kleinschmit et al., 2006). Dietary addition of ruminally protected Lys, and sometimes Met (second limiting AA), can, in some cases, increase milk yield of cows fed with corn-based DDGS (Kleinschmit et al., 2007a). The effect of substituting standard protein sources, such as soybean meal and canola cake, with DDGS is further influenced by heat treatment and, thereby, ruminal degradability of the protein in DDGS (Firkins et al., 1984; Kononoff et al., 2007; Boucher et al., 2009), by the protein quality of the forage, and the efficiency of rumen microbial protein production. In the present study, we investigated the use of DDGS, based on grains other than corn, at a marginally low dietary $\mathrm{CP}$ level in a grass-clover and corn silage-based ration. The experiment involved 2 dietary protein sources (DDGS or a soybean-canola mixture) at 2 levels of dietary CP (planned levels: 14 and $16 \% \mathrm{CP}$ ). Our aim was to evaluate the effect of protein source and protein level on DMI, milk yield, and milk quality.

\section{MATERIALS AND METHODS}

\section{Experimental Facilities and Animals}

The experiment was approved by The Animal Experiments Inspectorate under the Danish Veterinary and Food Administration (Glostrup, Denmark) and carried out from September to November 2013 at the Danish Cattle Research Centre at Aarhus University, Foulum, Denmark. A total of 24 Danish Holstein cows (8 primiparous cows, 16 multiparous cows) were included in the experiment, housed in a loose-housing system with slatted floors and cubicles with mattresses and sawdust as bedding. Cows had free access to water and to automatic feed bins (RIC system, Insentec, Marknesse, the Netherlands) distributing a partially mixed ration (PMR). The automatic milking unit (AMU; DeLaval AB, Tumba, Sweden) was equipped with a device delivering and recording the amount of concentrate fed and refusals.

\section{Experimental Design}

Four diets differing in level of $\mathrm{CP}$ and protein source were formulated and optimized using the NorFor model (Volden, 2011). Two diets with different levels of CP were formulated: a diet low in $\mathrm{CP}$ ( $\mathbf{L P}$, formulated to $14 \% \mathrm{CP}$ ) and one high in CP (HP, formulated to $16 \%$ CP). At each dietary CP level, DDGS (Agrodrank 90, Lantmännen Agroetanol, Sweden) based on $80 \%$ wheat and $20 \%$ triticale was substituted for a soybean-canolabeet pulp mixture (MIX), leading to 4 different PMR diets: LP-MIX, LP-DDGS, HP-MIX, and HP-DDGS. The ingredient composition (\% of DM) and chemical composition of these $4 \mathrm{PMR}$ diets are presented in Tables 1 and 2. The MIX diet was formulated to be approximately similar to DDGS in CP, fat, and NDF. Cows were blocked in 6 blocks of 4 cows according to parity, milk production, and DIM (average $228 \pm 91$ d). Within blocks, cows were randomly assigned to 1 of the 4 diets. Diets were fed for 3 wk, with 2 wk of adaptation and 1 wk of data collection. The diets were rotated according to a $4 \times 4$ Latin square design so that each group had a different diet at the same time. Each treatment group (6 cows) had access to all of the 3 feeders with the assigned ration. During diet rotation, the cows kept the same feeders to avoid a perturbation effect. The 4 PMR diets were fed ad libitum; only the concentrate mix allocated at the AMU was restricted (3 $\mathrm{kg} / \mathrm{d}$ of concentrate). The concentrate allowance allocated at each visit in the AMS was proportional to the length of time since the last milking for the individual cow. Concentrate was offered at a rate of $400 \mathrm{~g} / \mathrm{min}$ and cows were allowed up to $50 \%$ of the daily concentrate allowance per visit. If the full allowance was not fed, it was possible for cows to carry over up to $1.5 \mathrm{~kg}$ of concentrate to the next day.

\section{Recordings}

Individual daily DMI was summed from PMR, and AMU concentrate intake recorded at each visit to the Insentec feeder and the AMU. All feeds were sampled weekly and stored at $-20^{\circ} \mathrm{C}$ until pooled, and a representative sample was drawn for chemical analyses. Individual milk yield was recorded at each visit to the AMU and summed to obtain daily milk yield. Daily milking frequency was also recorded. Individual milk samples were collected weekly by the AMU using a modified automatic sampler (XMS, DeLaval; Løvendahl and Bjerring, 2006). The milk samples were taken over a 48-h period, starting on Sunday at noon and finishing on Tuesday at noon, preserved with Bronopol (BASF Corp., Florham Park, NJ), and kept cold $\left(2^{\circ} \mathrm{C}\right)$ 
Table 1. Diet ${ }^{1}$ composition and chemical composition of the $4 \mathrm{PMR}^{2}$ diets fed to Holstein cows

\begin{tabular}{|c|c|c|c|c|}
\hline DM $\%$ basis & LP-MIX & LP-DDGS & HP-MIX & HP-DDGS \\
\hline \multicolumn{5}{|l|}{ PMR } \\
\hline DDGS, $\%$ & - & 14.01 & - & 14.01 \\
\hline \multicolumn{5}{|l|}{ MIX } \\
\hline Soybean meal, \% & 5.61 & - & 9.00 & 3.40 \\
\hline Canola cake, \% & 4.20 & - & 6.75 & 2.55 \\
\hline Dried beet pulp, $\%$ & 4.20 & - & 6.75 & 2.55 \\
\hline Barley, \% & 8.49 & 8.49 & 4.25 & 4.25 \\
\hline Wheat, $\mathrm{NaOH}, \%$ & 8.49 & 8.49 & 4.25 & 4.25 \\
\hline Grass-clover silage, ${ }^{3} \%$ & 8.49 & 8.49 & 8.49 & 8.49 \\
\hline Whole-crop corn silage, ${ }^{3} \%$ & 48.8 & 48.8 & 48.8 & 48.8 \\
\hline \multicolumn{5}{|l|}{ At the $\mathrm{AMU}^{4}$} \\
\hline Concentrate, ${ }^{5} \%$ & 7.43 & 7.43 & 7.43 & 7.43 \\
\hline DDGS, $\%$ & 4.25 & 4.25 & 4.25 & 4.25 \\
\hline \multicolumn{5}{|l|}{ PMR chemical composition } \\
\hline $\mathrm{CP}, \%$ & 13.91 & 13.72 & 16.42 & 16.21 \\
\hline Crude fat, $\%$ & 2.43 & 2.90 & 2.57 & 3.08 \\
\hline NDF, \% & 38.82 & 38.82 & 39.82 & 39.73 \\
\hline Starch, \% & 21.68 & 21.71 & 15.82 & 15.91 \\
\hline Ash & 4.71 & 4.44 & 5.05 & 4.77 \\
\hline \multirow{2}{*}{\multicolumn{5}{|c|}{$\begin{array}{l}{ }^{1} \mathrm{LP}=\text { low protein diet }(14 \% \mathrm{CP}) ; \mathrm{HP}=\text { high protein } \operatorname{diet}(16 \% \mathrm{CP}) ; \mathrm{DDGS}=\text { dried distillers grains with } \\
\text { solubles; MIX = soybean-canola-beet pulp mixture. } \\
{ }^{2} \mathrm{PMR}=\text { partially mixed ration. }\end{array}$}} \\
\hline & & & & \\
\hline \multirow{2}{*}{\multicolumn{5}{|c|}{$\begin{array}{l}{ }^{3} \text { Forages information: grass-clover silage had } 22.2 \% \mathrm{DM}, 6.3 \% \text { ash, } 12.8 \% \mathrm{CP} \text {, and in vitro OM digestibility } \\
\text { (IVOS) being } 71.7 \text {; whole-crop corn silage had } 23.1 \% \mathrm{DM}, 3.2 \% \text { ash, } 8.5 \% \mathrm{CP}, 69.3 \mathrm{IVOS} \text {. } \\
{ }^{4} \mathrm{AMU}=\text { automatic milking unit. }\end{array}$}} \\
\hline & & & & \\
\hline \multicolumn{5}{|c|}{$\begin{array}{l}{ }^{5} \mathrm{AMU} \text { concentrate composition (\% DM): } 16.9 \% \text { sugar beet pulp, dried; } 16.8 \% \text { canola meal; } 14.6 \% \text { barley; } \\
14.6 \% \text { wheat; } 9.0 \% \text { soybean meal, dehulled; } 7.0 \% \text { sunflower meal, dehulled; } 7.0 \% \text { citrus pulp, dried; } 5.0 \% \text { wheat } \\
\text { bran; } 5.0 \% \text { alfalfa meal; } 3.0 \% \text { molasses, cane; } 0.7 \% \text { sodium chloride; } 0.3 \% \text { mineral premix; } 0.1 \% \text { magnesium } \\
\text { oxide. Minerals (per kg): Fe }=59 \mathrm{mg}, \mathrm{Zn}=46 \mathrm{mg}, \mathrm{Mn}=38 \mathrm{mg}, \mathrm{Cu}=8 \mathrm{mg}, \mathrm{I}=0.7 \mathrm{mg}, \mathrm{Se}=0.30 \mathrm{mg}, \mathrm{Co}= \\
0.11 \mathrm{mg} \text {; vitamins } \mathrm{A}=1,000 \mathrm{IU} / \mathrm{kg} \text {, vitamin } \mathrm{D}_{3} 1,000 \mathrm{IU} / \mathrm{kg}, \alpha \text {-tocopherol }=45 \mathrm{mg} / \mathrm{kg} \text {, vitamin } \mathrm{E}=50 \mathrm{mg} / \mathrm{kg} \text {. }\end{array}$} \\
\hline
\end{tabular}

until they were analyzed for fat, protein, lactose, and somatic cells. Within the same period, 1 milk sample was taken for analysis of fatty acids (FA). On Tuesday of the third week of each experimental period, $5 \mathrm{~L}$ of milk was sampled manually from the milking robot, and for each treatment composite samples, from at least 6 cows per treatment, were used for sensory analysis. Milk samples were also taken, using the aforementioned method, on Wednesday or Thursday of the second week of the experiment for sensory analysis of 1-wk-old milk.

The ECM $(3.140 \mathrm{MJ} / \mathrm{kg})$ was calculated according to Sjaunja et al. (1991) as

$$
\begin{aligned}
\mathrm{ECM}= & \text { milk yield } \times[(38.3 \times \text { fat }+24.2 \times \text { protein } \\
& +15.71 \times \text { lactose }+20.7) / 3.140],
\end{aligned}
$$

with ECM and milk yield in kilograms; fat, protein, and lactose monohydrate in grams per kilogram.

\section{Laboratory Analysis}

Feed Analysis. Dry matter content of grass-clover and whole-crop corn silages was determined by drying in a forced-air oven at $60^{\circ} \mathrm{C}$ for $48 \mathrm{~h}$. The results were used for weekly adjustments of PMR diet recipes. All feed samples were milled through a 1-mm screen before chemical analysis. Ash content was analyzed by weighing after combustion at $525^{\circ} \mathrm{C}$ for $6 \mathrm{~h}$ (AOAC International, 2000). Crude protein was calculated based on analysis of total N, according to the Dumas principle (Hansen, 1989), using a Vario MAX CN (Elementar Analysesysteme GmbH, Hanau, Germany). Crude fat was analyzed by Soxhlet extraction with petroleum ether (Soxtec 2050, Foss Analytical, Hillerød, Denmark) after hydrolyzing with $\mathrm{HCl}$ (Stoldt, 1952). Sugar was analyzed in replicate by the Luff-Schoorl method (European Community, 2012; 71/250/EEC). Starch was analyzed by an enzymatic colorimetric technique (Knudsen et al., 1987). Neutral detergent fiber was determined using the Fibertec M6 system (Foss Analytical), using heat-stable amylase to remove starch, followed by neutral detergent boiling, and reported as being ashfree (Mertens et al., 2002). Determination of in vitro digestibility of organic matter in forages was performed by anaerobic incubation in diluted rumen fluid for 48 $\mathrm{h}$, followed by $48 \mathrm{~h}$ of incubation of insoluble material with pepsin-HCl solution (Tilley and Terry, 1963). For concentrates, determination of in vitro digestibility was made by treating the samples with pepsin- $\mathrm{HCl}$ solu- 
Table 2. Chemical composition of the soybean-canola mixture and DDGS

\begin{tabular}{lrr}
\hline Item & MIX $^{1}$ & DDGS \\
\hline DM, \% & 88.4 & 94.2 \\
Ash, \% DM & 7.7 & 5.8 \\
EFOS, \% OM & 93.8 & 90.5 \\
CP, \% DM & 36.9 & 34.5 \\
NDF, \% DM & 21.9 & 21.2 \\
ADF-N, \% DM & 0.2 & 1.3 \\
ADF-N, \% N & 3.2 & 23.3 \\
Starch, \% DM & 0.5 & 1.7 \\
Sugar, \% DM & 9.9 & 4.0 \\
Crude fat, \% DM & 3.9 & 7.1 \\
Solubility, \% & $16^{4}$ & 24 \\
AA, g/kg of DM & & \\
Alanine & 14.2 & 13.3 \\
Arginine & 20.9 & 13.0 \\
Asparagine & 30.8 & 16.4 \\
Cysteine & 5.5 & 6.8 \\
Glutamine & 52.2 & 90.9 \\
Glycine & 14.4 & 13.9 \\
Histidine & 8.3 & 6.8 \\
Isoleucine & 14.5 & 12.0 \\
Leucine & 22.9 & 21.7 \\
Lysine & 18.6 & 6.1 \\
Methionine & 4.9 & 4.9 \\
Phenylalanine & 14.6 & 15.2 \\
Proline & 16.8 & 31.5 \\
Serine & 16.0 & 16.1 \\
Threonine & 13.2 & 10.3 \\
Valine & 16.8 & 15.3 \\
\hline NIX & & \\
\hline
\end{tabular}

${ }^{1}$ MIX = soybean-canola-beet pulp mixture.

${ }^{2}$ DDGS $=$ dried distillers grains with solubles.

${ }^{3} \mathrm{EFOS}=$ in vitro enzymatic method to determine digestibility (Weisbjerg and Hvelplund, 1993).

${ }^{4}$ The solubility of the soybean meal was $13 \%$, of the canola cake $22 \%$, and of the dried beet pulp $12 \%$.

tion, followed by incubation with enzymes (Weisbjerg and Hvelplund, 1993). Nitrogen bound in ADF was determined using the Fibertec system (Tecator AB, Höganäs, Sweden) for acid-detergent destruction (Van Soest, 1963), followed by $\mathrm{N}$ quantification in the filtered residue by a modified Kjeldahl method (AOAC International, 2000). Feed samples of MIX and DDGS were analyzed for AA (Cys, Met, Ala, Arg, Asp, Gln, Gly, His, Ile, Leu, Lys, Orn, Phe, Pro, Ser, Thr, and Val) according to the method described by Mason et al. (1980). Briefly, feed samples of MIX and DDGS were mixed with an oxidizing solution containing performic acid in a flask and sealed with an airtight film in a refrigerator at $0^{\circ} \mathrm{C}$. After $16 \mathrm{~h}$, a hydrolytic mixture was added to the flask. The flask was then boiled for $23 \mathrm{~h}$ at $110^{\circ} \mathrm{C}$ in order for hydrolysis to take place. The hydrolyzed mixture was then filtered through a 0.22- $\mu \mathrm{m}$ membrane filter and transferred to a Biochrom 30 AA analyzer (Laborservice Onken, Gründau, Germany) for analysis via ion exchange chromatography. Serine, Val, and Ile are prone to a moderate degree of oxidation by the addition of acid in the hydrolysis step, and their analyzed content was, therefore, corrected by a factor of 1.06 (Rudemo et al., 1980). The chemical composition of the 4 PMR diets, MIX, and DDGS are presented in Tables 1 and 2 .

Milk Composition and Sensory Analysis. Milk samples were cooled immediately to $4^{\circ} \mathrm{C}$ and subsequently analyzed for overall milk composition (fat, protein, lactose, and somatic cells) using a CombiFoss 4000 (Foss Electric A/S, Hillerød, Denmark). The milk samples for sensory analysis were pasteurized in a water bath at $65 \pm 2^{\circ} \mathrm{C}$ for $7 \mathrm{~min}$. Afterward, the samples were cooled in an ice bath and stored at $4^{\circ} \mathrm{C}$ for $24 \mathrm{~h}$ before carrying out descriptive sensory analysis, as described in Maciel et al. (2016). To summarize, a trained panel of 9 assessors attended a training session ( $2 \mathrm{~h}$ each) before the sensory evaluation, during which they were introduced to reference samples produced according to Hedegaard et al. (2006) and Maciel et al. (2016). A list of 15 sensory attributes, including aroma (cardboard, stored, popcorn, and metallic), appearance (color saturation and whiteness), flavor or taste (faded, metallic, cardboard, heat-treated milk, caramel, canned corn, creamy, and sweetness), and mouth feeling (creaminess), was agreed upon by the panelists before the evaluation. During training and sensory evaluation, the milk samples were randomly served in small plastic beakers with lids (Abena A/S, Aabenraa, Denmark) in amounts of approximately $50 \mathrm{~mL}$ after being kept at $12^{\circ} \mathrm{C}$ for $1 \mathrm{~h}$. The sensory evaluation of the milk samples was carried out in 3 replicates. The attributes were evaluated on a $15-\mathrm{cm}$, nonstructured, continuous scale, and the ratings were directly recorded electronically (Fizz Software, 2.30C, Biosystemes, Couternon, France). Training and sensory evaluation were conducted in accordance with the International Organization for Standardization (ISO, 1993) and carried out in a sensory laboratory fulfilling the requirements provided by the American Society for Testing and Materials (ASTM, 1986). For the training, 4 milk samples that varied in sensory quality were used. The sensory evaluation was performed on 8 samples (fresh and stored samples of LP-MIX, LP-DDGS, HPMIX, and HP-DDGS) that were tested by 9 panelists. The fresh samples were stored for $1 \mathrm{~d}$ and the stored samples for $7 \mathrm{~d}$ at $5^{\circ} \mathrm{C}$.

Determination of FA Profile. Analysis of FA in milk was performed based on the methods of Larsen et al. (2013), where fat was separated from milk by centrifugation and FA were methylated using sodium methylate. The FAME were quantified by the use of external standards (Supelco FAME mix C4-C24, Bellefonte, PA; PA and GLC 469 methyl ester standard from 
Nu-Chek Prep Inc., Elysian, MN), and the concentrations were calculated in grams per $100 \mathrm{~g}$ of identified milk FA.

\section{Statistical Analyses}

Feed Intake, Milk Production, Milk Fatty Acids. The effects of protein source (2 sources), protein level (2 levels), parity (primiparous or multiparous), and period (4 experimental periods) on daily milk yield $(\mathrm{kg} / \mathrm{d}), \mathrm{ECM}(\mathrm{kg} / \mathrm{d})$, fat $(\%$ and $\mathrm{kg} / \mathrm{d})$, protein $(\%$ and $\mathrm{kg} / \mathrm{d}$ ), milking frequency, PMR intake ( $\mathrm{kg}$ of $\mathrm{DM} / \mathrm{d}$ ), concentrate intake at AMU $(\mathrm{kg} / \mathrm{d})$, and FA $(\mathrm{g} / 100 \mathrm{~g}$ of FA) were analyzed using the PROC MIXED model of the statistical software SAS (SAS version 9.3, SAS Institute Inc., Cary, NC) with the cow as experimental unit. The initial model [1] with all the interactions was then reduced to model [2] including only the significant interaction:

$$
\begin{gathered}
\mathrm{Y}_{\mathrm{ijk} k m}=\mu+\mathrm{L}_{\mathrm{i}}+\mathrm{S}_{\mathrm{j}}+\mathrm{P}_{\mathrm{k}}+(\mathrm{LS})_{\mathrm{ij}}+(\mathrm{LP})_{\mathrm{ik}} \\
+(\mathrm{SP})_{\mathrm{jk}}+(\mathrm{LSP})_{\mathrm{ijk}}+\mathrm{T}_{1}+\mathrm{C}_{\mathrm{ijm}}+\varepsilon_{\mathrm{ijk} \mathrm{m}},
\end{gathered}
$$

and

$$
\begin{aligned}
\mathrm{Y}_{\mathrm{ijklm}}=\mu+ & \mathrm{L}_{\mathrm{i}}+\mathrm{S}_{\mathrm{j}}+(\mathrm{LS})_{\mathrm{ij}}+\mathrm{P}_{\mathrm{k}}+\mathrm{T}_{1} \\
& +\mathrm{C}_{\mathrm{ijm}}+\varepsilon_{\mathrm{ijklm}},
\end{aligned}
$$

where $Y_{\mathrm{ijklm}}$ is the dependent variable, $\mu$ is the overall mean, and the model includes the effects of the ith protein level $\mathrm{L}(\mathrm{i}=\mathrm{high}$ or low), the jth protein source $\mathrm{S}(\mathrm{j}=$ DDGS or MIX), the kth parity $\mathrm{P}(\mathrm{k}=$ primiparous, multiparous), the lth period $\mathrm{T}(\mathrm{l}=1$ to 4$)$; (LS) ij, $(\mathrm{LP})_{\mathrm{ik}},(\mathrm{SP})_{\mathrm{jk}}$, and (LSP) $)_{\mathrm{ijk}}$ denote the 2- and 3-way interactions; $\mathrm{C}_{\mathrm{ijm}}$ is the random effect of the mth cow within ith protein level and jth protein source; and $\varepsilon_{\mathrm{ijklm}}$ is the residual error. Results are presented in Table 3 containing the least squares means $( \pm \mathrm{SEM})$ and the $P$-values of the overall F-tests for the fixed effects.

Sensory Analysis. To study the effect of the 4 diets on the sensory attributes in fresh and stored milk samples, a 3-way ANOVA mixed model was applied, the fixed effects being the assessor, the diet (among the 4 diets studied), and the storage duration ( 0 or $7 \mathrm{~d}$ ). The 2-way interaction diet $\times$ storage was also included in the model. To reveal the differences between the milk samples, the Bonferroni method was used for post-hoc testing (Næs et al., 2010).

\section{RESULTS AND DISCUSSION}

\section{Diet Composition}

The ingredients (\% DM) and chemical composition of the 4 diets are presented in Tables 1 and 2. Diets were formulated for 2 different levels of CP (14 and $16 \%$ ) with 2 different feed protein sources (DDGS or MIX). Slight variations of nutrient composition existed between the 2 protein sources; MIX had more CP, fiber, ash, and sugar, as well as a higher in vitro digestibility than DDGS, whereas DDGS had more $\mathrm{N}$ bound in ADF and starch than MIX. The proportion of NDF in MIX and DDGS was similar (Table 2). Compared with corn DDGS, wheat DDGS has a higher content of CP and a lower fat content (Pedersen et al., 2014). The diets were very close to the CP levels aimed for

\begin{tabular}{|c|c|c|c|c|c|c|c|c|c|c|c|}
\hline Item & \multicolumn{4}{|c|}{ Diet $^{1}$} & & & & & & & \\
\hline Intake PMR, $\mathrm{kg} / \mathrm{d}$ & 18.18 & 18.51 & 18.66 & 19.20 & 17.06 & 20.16 & 0.71 & 0.02 & 0.16 & 0.47 & $<0.01$ \\
\hline Intake at $\mathrm{AMU}^{2}, \mathrm{~kg} / \mathrm{d}$ & 2.44 & 2.69 & 2.63 & 2.56 & 2.57 & 2.59 & 0.15 & 0.80 & 0.41 & 0.15 & 0.91 \\
\hline Milking frequency, /d & 2.47 & 2.64 & 2.64 & 2.61 & 2.66 & 2.52 & 0.18 & 0.27 & 0.24 & 0.12 & 0.53 \\
\hline Fat, $\%$ & 4.51 & 4.60 & 4.55 & 4.62 & 4.45 & 4.69 & 0.25 & 0.51 & 0.12 & 0.78 & 0.42 \\
\hline Fat, $\mathrm{kg} / \mathrm{d}$ & 1.37 & 1.38 & 1.50 & 1.46 & 1.36 & 1.49 & 0.06 & $<0.01$ & 0.57 & 0.31 & 0.10 \\
\hline Protein, \% & 3.56 & 3.58 & 3.62 & 3.63 & 3.42 & 3.77 & 0.04 & 0.04 & 0.57 & 0.98 & $<0.01$ \\
\hline Protein, $\mathrm{kg} / \mathrm{d}$ & 1.08 & 1.08 & 1.20 & 1.15 & 1.04 & 1.21 & 0.11 & $<0.01$ & 0.24 & 0.26 & $<0.01$ \\
\hline
\end{tabular}
(Table 1), similar in NDF, and close in other param-

Table 3. Yields of milk and ECM, percentages of milk fat and protein, milking frequency, intake of partial mixed ration (PMR), and intake of concentrates at the milking robot

${ }^{1} \mathrm{LP}=$ low protein $\operatorname{diet}(14 \% \mathrm{CP}) ; \mathrm{HP}=$ high protein $\operatorname{diet}(16 \% \mathrm{CP}) ; \mathrm{MIX}=$ soybean-canola-beet pulp mixture; DDGS = dried distillers grains with solubles.

${ }^{2} \mathrm{AMU}=$ automatic milking unit. 
eters (crude fat and ash), except for starch, where the HP diets contained less than the LP diets. Thus, we made a decision to maintain $\mathrm{CP}$ levels in the HP diets at the expense of starch. The AA profile of DDGS was within the range of those described by De Boever et al. (2014) for wheat DDGS and blended DDGS. The MIX had more AA than DDGS, a similar concentration of Met, but a higher concentration of Lys (18.6 vs. $6.1 \mathrm{~g} /$ $\mathrm{kg}$ of DM, respectively). Lysine appears to be the first liming AA in DDGS and may cause a slight decrease in milk protein content (Nichols et al., 1998; Kleinschmit et al., 2007b), mainly for diets containing more than 30\% DDGS (Kalscheur, 2005; Kononoff et al., 2007), reflecting the limitation in rumen undegradable Lys in DDGS. Ethanol processing plants have improved the fermentation and drying process, as overheating during drying was found to reduce Lys availability (Zijlstra and Beltranena, 2009) and produces a DDGS of higher quality (Whitney and Shurson, 2004). The protein solubility was higher for DDGS compared with the MIX (24 vs. 16\%) but still quite low and similar to that found by Wohlt et al. (1973), who reported a solubility of $26.3 \%$ for corn DDGS. The solubility of DDGS is higher than those of the initials products due to an increase of albumin and globulin (Wohlt et al., 1973).

\section{Effect of DDGS on DMI}

In general, for all the variables studied, we found no significant interaction between protein level and protein source (Table 3). Concentrate intake at the AMU was not affected by the protein level or the protein source. We observed no difference in PMR intake between the protein sources, but the PMR intake was higher for the HP diets compared with the LP diets $(P=0.02)$.

Cunningham et al. (1996) and Leonardi et al. (2003) fed diets with CP levels from 16.5 to $18.5 \%$ and 16.1 to $18.9 \%$, respectively, and reported no effect of protein level on DMI. However, several publications indicated that DMI increases with increasing proportions of dietary $\mathrm{CP}$ when rations low in protein are supplemented (Broderick, 2003; Weisbjerg et al., 2010; Alstrup et al., 2014). Broderick (2003) observed a linear increase in DMI when CP was increased from 15.1 to $18.3 \%$; Hymøller et al. (2014) and Alstrup et al. (2014) found higher DMI for cows fed 16\% CP compared with $14 \%$ $\mathrm{CP}$. Low dietary CP content can decrease fiber digestion and, thereby, DM digestibility of the feed (Allen, 2000). This supports increased dietary protein being an important driver for the increased DMI with the HP diets in the present study. However, the increased dietary protein level with the HP diets were confounded with a decreased dietary starch level from barley. The proportion of dietary barley starch has been found to correlate negatively to rumen $\mathrm{pH}$ and DMI at dietary barley inclusion rates from 12.25 to $49.00 \%$ and around $33 \%$ dietary starch (Overton et al., 1995), which is far above the levels in the present study (Table 1). In the meta-analysis of Hollmann et al. (2011), DMI was negatively related to the proportion of starch only when diets contained more than 34 or $28 \%$ starch for control and corn-based DDGS diets, respectively, and only with lower-producing cows $(<30 \mathrm{~kg}$ of milk/d). In the present study, the dietary concentrations of starch were well below these levels and milk production was above $30 \mathrm{~kg}$ of milk/d (Tables 1 and 3). Ipharraguerre and Clark (2005) also reported the combined effect of protein level and starch on DMI, DMI being lower for the low-protein level diet (CP around 15\%) rich in starch than for the high-protein level diet (CP around $17 \%$ ) lower in starch. This indicates that, in the present study, the increased DMI with the HP diets were primarily driven by the increased dietary protein, whereas the decreased dietary starch could also play a role.

Concerning the protein source, a previous study, using DDGS based on grain other than corn, is in accordance with the present results, as DMI was not affected by substituting a soybean-canola mixture with increasing proportions of DDGS in the diet (Gaillard et al., 2017). Hollmann et al. (2011) also reported, in a meta-analysis of 16 peer-reviewed publications, that DMI was not influenced by the proportion of corn-based DDGS included in the diet. Only 1 study (Nichols et al., 1998) reported a higher DMI from a diet with corn DDGS compared with a diet with soybean meal, maybe because the 12 cows used to make the groups in their experiment were only balanced for DIM and not for milk production. As the low protein level in the present study was obviously limited in protein, as planned, the absence of an interaction between protein source and protein level indicate that the protein quality was similar for the 2 protein sources.

\section{Effect of DDGS on Milk Production and Composition}

Milk and ECM yields were higher for the HP diets compared with the LP diets, as expected, and were not affected by protein source. Milking frequency was not affected by protein source or protein level. We found no effect of protein source or protein level on milk fat content, whereas milk fat yield was reduced in LP diets compared with HP diets. As expected, total milk protein yield and milk protein content were higher for the cows fed the HP diets compared with the LP diets. We noted no effect of the protein source on the total milk protein yield or milk protein content (Table 3). 
These milk yield and ECM results are in accordance with the results of Hymøller et al. (2014) and Alstrup et al. (2014), indicating a higher DMI, milk yield, and ECM for the cows fed $16 \%$ CP diet compared with $14 \%$ CP. Colmenero and Broderick (2006) also fed cows with a control diet containing $13.5 \% \mathrm{CP}$, but did not find a milk yield difference when compared with the milk yield of cows fed a $19.4 \%$ CP diet. They only found a trend for a quadratic response to CP level for milk yield. Broderick (2003) observed an increase in milk yield when CP increased from 15.1 to $16.7 \%$, but not from 16.7 to $18.3 \%$. The increase in milk and ECM yields reported in the present study are probably mainly due to the increase in DMI, but possibly also to an increase of digestibility, which explains the more pronounced increase in yields than DMI when dietary $\mathrm{CP}$ is increased (Colmenero and Broderick, 2006); this observation was also reported in Weisbjerg et al. (2012). We found no interaction between $\mathrm{CP}$ level and parity, when normally the response to increased nutrient supply is higher in older cows (Bossen and Weisbjerg, 2009). Concerning the effect of protein source, Janicek et al. (2008) and Mjoun et al. (2010) found similar milk yields when feeding corn DDGS or soybean diets as a protein source. Other studies have demonstrated that milk yield increased when corn DDGS was fed to dairy cows in mid lactation, compared with cows fed soybean control diets without DDGS (Anderson et al., 2006; Kleinschmit et al., 2006). In Anderson et al. (2006) and Kleinschmit et al. (2006), the increase in milk production when feeding corn DDGS might be due to the fact that they did not balance the fat content of all diets (crude fat as percent of DM). Anderson et al. (2006) fat content was $2.29 \%$ for the control diet, $3.06 \%$ for the DDGS included at $10 \%$, and $4.18 \%$ for the DDGS included at 20\%; for Kleinschmit et al. (2006), however, fat content was $2.18 \%$ for the soybean control diet, and, on average, $4.56 \%$ for the 3 DDGS used. Thus, part of the response in those studies might have been attributed to the increased fat content of the corn DDGS diet. The modest difference in crude fat concentration in the present study was not expected to affect the production response.

Leonardi et al. (2005) and Colmenero and Broderick (2006) found that milk fat content increased when increasing the level of CP in the diet (from 16.1 to $18.9 \%$ and from 13.5 to $19.4 \%$ respectively), whereas Broderick (2003) did not find differences among diets containing between 15.1 and $18.4 \%$ CP. When looking at milk fat yields, a study by Leonardi et al. (2003) indicated an increase in yield with increasing content of $\mathrm{CP}$ in the diet, whereas Broderick (2003) and Colmenero and Broderick (2006) observed an increase up to a threshold (16.7 and $16.5 \% \mathrm{CP}$, respectively) and a decrease in milk fat yield above this threshold. Concerning the source of protein, the results of Mjoun et al. (2010) are in accordance with the present study, as they found no differences in milk fat yield between corn DDGS diet and soybean meal diets. However, Anderson et al. (2006) found that milk fat yield was higher for corn DDGS diets compared with soybean diets, whereas the fat content was similar.

Colmenero and Broderick (2006) found that increased dietary CP level did not affect milk protein content, but milk protein yield had a trend for a quadratic (maximum at $16.5 \% \mathrm{CP}$ ) and linear response. Broderick (2003) also found that protein content and yield increased when diets increased their CP content from 15.1 to $16.7 \%$, but above $16.7 \%$ no further difference was observed. Leonardi et al. (2003) found no effect of protein level on milk protein yield, but a decrease in milk protein yield was observed when CP in the diet increased from 16.1 to $18.9 \%$. Our increase in protein in milk with dietary protein level is partly due to the increased DMI with increased dietary protein. Concerning the effect of the protein source, Mjoun et al. (2010) found that cows fed corn DDGS had higher milk protein content and yield than cows fed soybean meal. Results from Anderson et al. (2006) indicate that the milk protein content was similar for cows fed a corn DDGS diet and cows fed a soybean meal diet, whereas Janicek et al. (2008) and Anderson et al. (2006) found that milk protein yield increased with increasing proportion of corn DDGS in the diet from 10 to $30 \%$ of dietary DM. In these 2 studies, this increase was attributed to the increase in DMI, leading to more energy being available for milk protein synthesis. In our case, as DMI was not affected by the protein source, it explains the similar yields of total milk protein between the DDGS and MIX diets.

\section{Milk Quality}

Milk FA. As presented in Table 4, the protein source and level affected some FA concentrations. The concentrations of the medium-long chain FA (C11-C17) were lower for the DDGS diets compared with the MIX diets, whereas the different C18 FA and CLA9-11 in milk were higher for the DDGS diets compared with the MIX diets. Cows fed the LP diets produced milk with higher concentrations of $\mathrm{C} 15$ and $\mathrm{C} 16$, and lower concentrations of $\mathrm{C} 18$ and trans FA, than cows fed the HP diets. All the differences observed were, however, quite small, and feeding DDGS as a protein source did not have a great effect on FA profile. The largest relative difference was observed for linoleic acid, as its concentration increased by approximatively $20 \%$ when DDGS was fed. Our results are similar to those reported by Testroet et al. (2015) and, as linoleic acid was the main 
Table 4. Effect of protein level (LP or HP) and protein source (DDGS or MIX) on the proportion of milk fatty acids (g/100 g) in milk

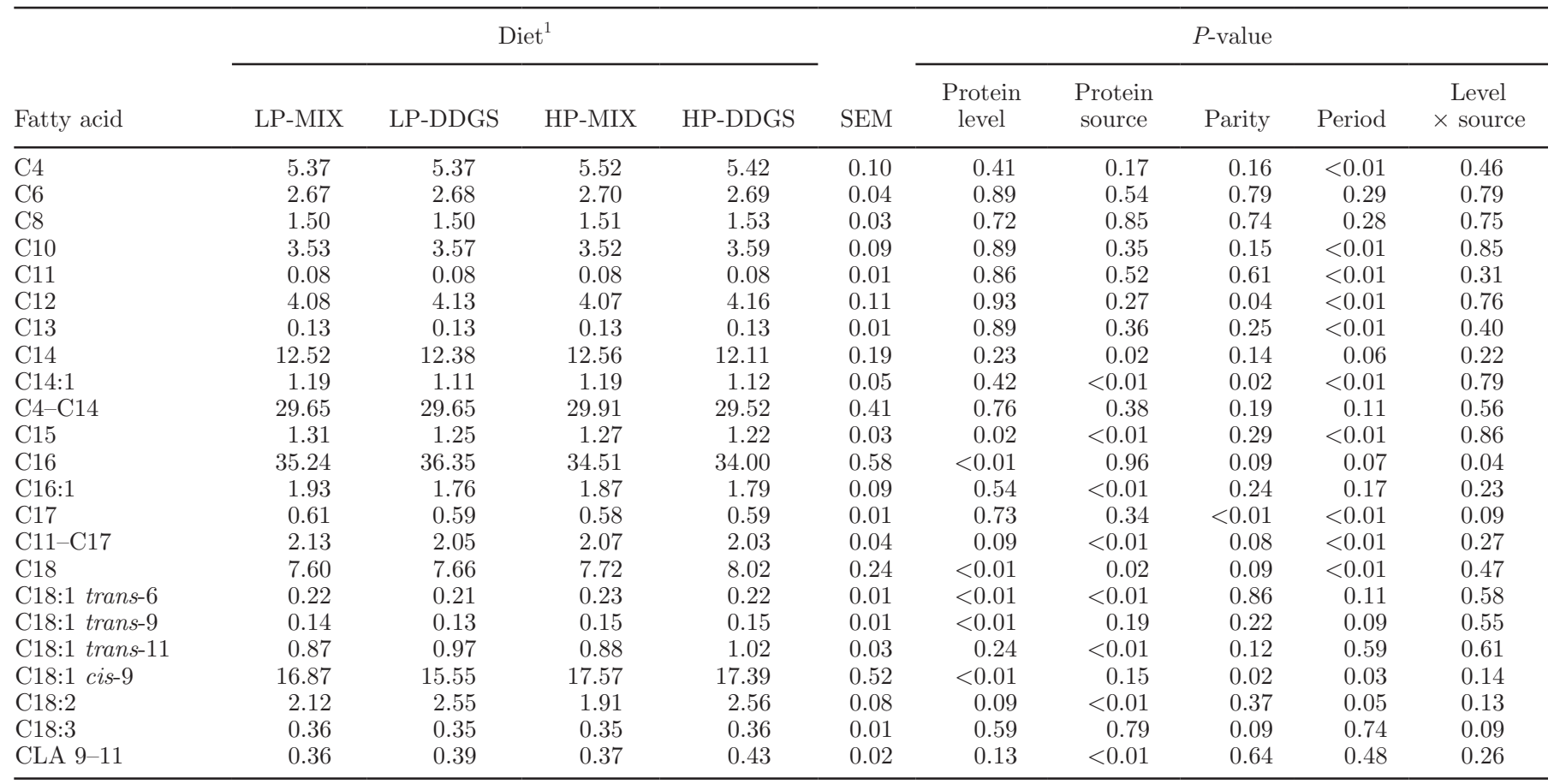

${ }^{1} \mathrm{LP}=$ low protein diet $(14 \% \mathrm{CP}) ; \mathrm{HP}=$ high protein $\operatorname{diet}(16 \% \mathrm{CP}) ; \mathrm{MIX}=$ soybean-canola-beet pulp mixture; DDGS = dried distillers grains with solubles.

FA of DDGS, this result is not surprising (Schingoethe et al., 1999). The DDGS increases the UFA content in milk because wheat and triticale contain between 55 and $60 \%$ of its FA as C18:2 (Chung and Ohm, 2000), some of which escapes the rumen without biohydrogenation, thereby increasing the proportion of UFA in milk, such as C18:1 and C18:2. The results also indicate human health advantages, as the milk produced from cows fed DDGS is lower in C14 and higher in CLA9-11, C14 being one of the FA responsible for the increase in low-density lipoprotein in blood (Parodi, 2009) and CLA having different properties, such as the inhibition of carcinogenesis, the reduction of atherosclerosis, being hypocholesterolemic, reducing adipose tissue mass, and the reduction of symptoms of diabetes mellitus type II (Pariza et al., 2001; Roche et al., 2002; Whigham et al., 2007).

Sensory Analysis. The 8 samples differed only in 4 attributes: stored aroma, cardboard flavor, metallic aroma, and metallic flavor. We found no effect of protein level or protein source on the quality of fresh milk samples. When comparing only the 4 stored milk samples, no differences were noted for the 4 attributes studied (Table 5). A high-CP diet may result in a cowybarny flavor of milk (Drake, 2007) due to the formation of skatole (Coppa et al., 2011), but such off-flavor was not observed at the high $\mathrm{CP}$ levels in the present study. The experiment of Reyes Sánchez et al. (2006), performed on creole dairy cows fed different levels of the foliage Moringa oleifera (high in CP), indicates no organoleptic differences between the diets. Testroet et al. (2015) hypothesized that greater inclusion of DDGS in the ration would contribute to the development of the off-flavors in milk due to an increase in UFA in milk. However, when DDGS was included from 10 to $25 \%$ of diet DM, they reported no off-flavors, in accordance with our results. The LP-DDGS milk had 3 attributes (cardboard flavor, metallic aroma, and metallic flavor) that increased in intensity with $7 \mathrm{~d}$ of storage $(P<0.05)$. Raw milk is spontaneously oxidized within $5 \mathrm{~d}$ of collection and leads to an oxidized flavor in milk (Timmons et al., 2001), which might explain the results observed for LP-DDGS after $7 \mathrm{~d}$ of storage. These results also indicate that, when the $\mathrm{CP}$ level is low, the source of protein will affect the sensory quality of the fresh and stored milk.

\section{CONCLUSIONS}

Feed intake, milk and milk protein yields, and protein in milk increased with the high dietary protein level $(16 \% \mathrm{CP})$ compared with the low dietary protein level $(14 \% \mathrm{CP})$. We found no effect of substituting the soybean-canola mixture with DDGS, indicating 
Table 5. Sensory quality of milk samples; only the attributes that differ significantly are shown

\begin{tabular}{lccccc}
\hline Diet $^{1}$ & Milk $^{2}$ & $\begin{array}{c}\text { Stored } \\
\text { aroma }\end{array}$ & $\begin{array}{c}\text { Metallic } \\
\text { aroma }\end{array}$ & $\begin{array}{c}\text { Cardboard } \\
\text { flavor }\end{array}$ & $\begin{array}{c}\text { Metallic } \\
\text { flavor }\end{array}$ \\
\hline LP-MIX & Fresh & $2.5^{\mathrm{b}}$ & $1.4^{\mathrm{b}}$ & $1.0^{\mathrm{b}}$ & $2.7^{\mathrm{ab}}$ \\
HP-MIX & Fresh & $5.7^{\mathrm{ab}}$ & $2.2^{\mathrm{ab}}$ & $2.3^{\mathrm{b}}$ & $4.1^{\mathrm{bb}}$ \\
LP-DDGS & Fresh & $2.4^{\mathrm{b}}$ & $1.1^{\mathrm{b}}$ & $1.1^{\mathrm{b}}$ & $1.2^{\mathrm{b}}$ \\
HP-DDGS & Fresh & $3.4^{\mathrm{b}}$ & $1.7^{\mathrm{ab}}$ & $2.4^{\mathrm{b}}$ & $2.2^{\mathrm{ab}}$ \\
LP-MIX & Stored & $4.9^{\mathrm{ab}}$ & $4.6^{\mathrm{ab}}$ & $2.5^{\mathrm{b}}$ & $4.4^{\mathrm{ab}}$ \\
HP-MIX & Stored & $4.4^{\mathrm{ab}}$ & $2.6^{\mathrm{ab}}$ & $6.9^{\mathrm{a}}$ & $7.2^{\mathrm{a}}$ \\
LP-DDGS & Stored & $6.1^{\mathrm{ab}}$ & $5.5^{\mathrm{a}}$ & $5.4^{\mathrm{ab}}$ & $5.8^{\mathrm{ab}}$ \\
HP-DDGS & Stored & $6.4^{\mathrm{a}}$ & $5.0^{\mathrm{ab}}$ & & \\
\hline
\end{tabular}

${ }_{\mathrm{a}, \mathrm{b}}$ Different letters in a column indicate significant differences in the specific attribute at $P<0.05$.

${ }^{1} \mathrm{LP}=$ low protein diet $(14 \% \mathrm{CP}) ; \mathrm{HP}=$ high protein $\operatorname{diet}(16 \% \mathrm{CP}) ; \mathrm{MIX}=$ soybean-canola-beet pulp mixture; DDGS = dried distillers grains with solubles.

${ }^{2}$ Fresh milk analyzed at $\mathrm{d} 1$, or stored milk analyzed at $\mathrm{d} 7$.

that the protein quality of the DDGS was not inferior to that of the soybean-canola mixture. Moreover, we observed no sensory problems when comparing fresh milk with stored milk, and taste was unaffected by DDGS. Milk FA profile changed slightly with DDGS and with the protein level. In conclusion, DDGS based on a grain mixture excluding corn can substitute for a soybean-canola mixture without affecting feed intake, milk yield, milk quality, and sensory quality at both a low and high dietary CP level.

\section{ACKNOWLEDGMENTS}

This project was financed by The Danish Milk Levy Fund with contributions from AgroTech (Aarhus, Denmark), DLG (Aarhus, Denmark), Arla Foods amba (Aarhus, Denmark), Danish Cattle Research Centre (Tjele, Denmark), and Aarhus University (Aarhus, Denmark). Grain DDGS was delivered by Lantmännen Agroetanol, Sweden. We acknowledge the staff at the Danish Cattle Research Centre for their highly committed effort in running the experiment. We acknowledge the data handling staff and laboratory staff for their effective efforts to bring about data.

\section{REFERENCES}

Allen, M. S. 2000. Effects of diet on short-term regulation of feed intake by lactating dairy cattle. J. Dairy Sci. 83:1598-1624.

Alstrup, L., M. R. Weisbjerg, L. Hymøller, M. K. Larsen, P. Lund, and M. O. Nielsen. 2014. Milk production response to varying protein supply is independent of forage digestibility in dairy cows. J. Dairy Sci. 97:4412-4422.

Anderson, J. L., D. J. Schingoethe, K. F. Kalscheur, and A. R. Hippen. 2006. Evaluation of dried and wet distillers grains included at two concentrations in the diets of lactating dairy cows. J. Dairy Sci. 89:3133-3142.

AOAC International. 2000. Official Methods of Analysis. 17th ed. AOAC Int., Rockville, MD.

ASTM. 1986. Physical Requirement Guidelines for Sensory Evaluation Laboratories. J. Eggert and K. Zook, ed. ASTM International, West Conshohocken, PA. https://doi.org/10.1520/STP913-EB.
Belyea, R. L., K. D. Rausch, T. E. Clevenger, V. Singh, D. B. Johnston, and M. E. Tumbleson. 2010. Sources of variation in composition of DDGS. Anim. Feed Sci. Technol. 159:122-130.

Bossen, D., and M. R. Weisbjerg. 2009. Allocation of feed based on individual dairy cow live weight changes II: Effect on milk production. Livest. Sci. 126:273-285.

Boucher, S. E., S. Calsamiglia, C. M. Parsons, M. D. Stern, M. R. Moreno, M. Vazquez-Anon, and C. G. Schwab. 2009. In vitro digestibility of individual amino acids in rumen-undegraded protein: The modified three-step procedure and the immobilized digestive enzyme assay. J. Dairy Sci. 92:3939-3950.

Broderick, G. A. 2003. Effects of varying dietary protein and energy levels on the production of lactating dairy cows. J. Dairy Sci 86:1370-1381.

Chrenkova, M., Z. Ceresnakova, Z. Formelova, M. Polacikova, Z. Mlynekova, and P. Flak. 2012. Chemical and nutritional characteristics of different types of DDGS for ruminants. J. Anim. Feed Sci. $21: 425-435$.

Chung, O. K., and J. B. Ohm. 2000. Cereal lipids. Pages 417-477 in Handbook of Cereal Science and Technology. CRC Press, New York, NY

Colmenero, J. J. O., and G. A. Broderick. 2006. Effect of dietary crude protein concentration on milk production and nitrogen utilization in lactating dairy cows. J. Dairy Sci. 89:1704-1712.

Coppa, M., B. Martin, P. Pradel, B. Leotta, A. Priolo, and V. Vasta 2011. Effect of a hay-based diet or different upland grazing systems on milk volatile compounds. J. Agric. Food Chem. 59:4947-4954.

Cunningham, K. D., M. J. Cecava, T. R. Johnson, and P. A. Ludden. 1996. Influence of source and amount of dietary protein on milk yield by cows in early lactation. J. Dairy Sci. 79:620-630.

De Boever, J. L., M. C. Blok, S. Millet, J. Vanacker, and S. De Campeneere. 2014. The energy and protein value of wheat, maize and blend DDGS for cattle and evaluation of prediction methods. Animal 8:1839-1850.

Drake, M. A. 2007. Invited review: Sensory analysis of dairy foods. J. Dairy Sci. 90:4925-4937.

European Community. 2012. First commission directive of 15 June 1971 establishing Community methods of analysis for the official control of feeding-stuffs (71/250/EEC). Accessed Jan. 5, 2017. http://eur-lex.europa.eu/legal-content/EN/TXT/PDF/?uri= CELEX:32009R0152\&from $=$ EN

Firkins, J. L., L. L. Berger, G. C. Fahey Jr., and N. R. Merchen. 1984. Ruminal nitrogen degradability and escape of wet and dry distillers grains and wet and dry corn gluten feeds. J. Dairy Sci. 67:1936-1944.

Gaillard, C., M. T. Sørensen, M. Vestergaard, M. R. Weisbjerg, A. Basar, M. K. Larsen, H. Martinussen, U. Kidmose, and J. Sehested. 2017. Effect of substituting soybean meal and canola cake with grain based dried distillers grains with solubles as a protein source on feed intake, milk production and milk quality in dairy cows. J. Dairy Sci. https://doi.org/10.316/jds.2017-12654. 
Hansen, B. 1989. Determination of nitrogen as elementaty N, an alternative to Kjeldahl. Acta Agric. Scand. 39:113-118.

Hedegaard, R. V., D. Kristensen, J. H. Nielsen, M. B. Frost, H. Ostdal, J. E. Hermansen, M. Kroger-Ohlsen, and L. H. Skibsted. 2006. Comparison of descriptive sensory analysis and chemical analysis for oxidative changes in milk. J. Dairy Sci. 89:495-504.

Hollmann, M., M. S. Allen, and D. K. Beede. 2011. Diet fermentability influences lactational performance responses to corn distillers grains: A meta-analysis. J. Dairy Sci. 94:2007-2021.

Hymøller, L., L. Alstrup, M. K. Larsen, P. Lund, and M. R. Weisbjerg. 2014. High-quality forage can replace concentrate when cows enter the deposition phase without negative consequences for milk production. J. Dairy Sci. 97:4433-4443.

Hynes, D. N., S. Stergiadis, A. Gordon, and T. Yan. 2016a. Effects of concentrate crude protein content on nutrient digestibility, energy utilization, and methane emissions in lactating dairy cows fed fresh-cut perennial grass. J. Dairy Sci. 99:8858-8866.

Hynes, D. N., S. Stergiadis, A. Gordon, and T. Yan. 2016b. Effects of crude protein level in concentrate supplements on animal performance and nitrogen utilization of lactating dairy cows fed freshcut perennial grass. J. Dairy Sci. 99:8111-8120.

Ipharraguerre, I. R., and J. H. Clark. 2005. Varying protein and starch in the diet of dairy cows. I. Effects on performance and nitrogen utilization for milk production. J. Dairy Sci. 88:2556-2570.

ISO. 1993. ISO 8586-1. General Guidelines for the Selection, Training and Monitoring of Assessors. International Organization for Standardization, Geneva, Switzerland.

Janicek, B. N., P. J. Kononoff, A. M. Gehman, and P. H. Doane. 2008. The effect of feeding dried distillers grains plus solubles on milk production and excretion of urinary purine derivatives. J. Dairy Sci. 91:3544-3553

Kalscheur, K. F. 2005. Impact of feeding distillers grains on milk fat, protein, and yield. Proc. Distillers Grains Technology Council, 9th Annual Symposium, Louisville, KY. DGTC, Louisville, KY.

Kleinschmit, D. H., J. L. Anderson, D. J. Schingoethe, K. F. Kalscheur, and A. R. Hippen. 2007a. Ruminal and intestinal degradability of distillers grains plus solubles varies by source. J. Dairy Sci. 90:2909-2918

Kleinschmit, D. H., D. J. Schingoethe, A. R. Hippen, and K. F. Kalscheur. 2007b. Dried distillers grains plus solubles with corn silage or alfalfa hay as the primary forage source in dairy cow diets. J. Dairy Sci. 90:5587-5599.

Kleinschmit, D. H., D. J. Schingoethe, K. F. Kalscheur, and A. R. Hippen. 2006. Evaluation of various sources of corn dried distillers grains plus solubles for lactating dairy cattle. J. Dairy Sci. 89:4784-4794.

Knudsen, K. E. B., P. Aman, and B. O. Eggum. 1987. Nutritive value of danish grown barley varieties. 1. Carbohydrates and other major constituents. J. Cereal Sci. 6:173-186.

Kononoff, P. J., S. K. Ivan, and T. J. Klopfenstein. 2007. Estimation of the proportion of feed protein digested in the small intestine of cattle consuming wet corn gluten feed. J. Dairy Sci. 90:2377-2385.

Larsen, M. K., U. Kidmose, T. Kristensen, P. Beaumont, and G. Mortensen. 2013. Chemical composition and sensory quality of bovine milk as affected by type of forage and proportion of concentrate in the feed ration. J. Sci. Food Agric. 93:93-99.

Leonardi, C., S. Bertics, and L. E. Armentano. 2005. Effect of increasing oil from distillers grains or corn oil on lactation performance. J. Dairy Sci. 88:2820-2827.

Leonardi, C., M. Stevenson, and L. E. Armentano. 2003. Effect of two levels of crude protein and methionine supplementation on performance of dairy cows. J. Dairy Sci. 86:4033-4042.

Liu, K. 2008. Particle size distribution of distillers dried grains with solubles (DDGS) and relationships to compositional and color properties. Bioresour. Technol. 99:8421-8428.

Løvendahl, P., and M. A. Bjerring. 2006. Detection of carryover in automated milk sampling equipment. J. Dairy Sci. 89:3645-3652.

Maciel, G. M., N. A. Poulsen, M. K. Larsen, U. Kidmose, C. Gaillard, J. Sehested, and L. B. Larsen. 2016. Good sensory quality and cheesemaking properties in milk from Holstein cows managed for an 18-month calving interval. J. Dairy Sci. 99:8524-8536.
Mason, V. C., S. Bech-Andersen, and M. Rudemo. 1980. Hydrolysate preparation for amino acid determinations in feed constituents. Z Tierphysiol. Tierernahr. Futtermittelkd. 43:35-48.

Mertens, D. R., M. Allen, J. Carmany, J. Clegg, A. Davidowicz, M. Drouches, K. Frank, D. Gambin, M. Garkie, B. Gildemeister, D. Jeffress, C. S. Jeon, D. Jones, D. Kaplan, G. N. Kim, S. Kobata, D. Main, X. Moua, B. Paul, J. Robertson, D. Taysom, N. Thiex, J. Williams, and M. Wolf. 2002. Gravimetric determination of amylase-treated neutral detergent fiber in feeds with refluxing in beakers or crucibles: Collaborative study. J. AOAC Int. 85:1217-1240.

Mjoun, K. K. F. Kalscheur, A. R. Hippen, and D. J. Schingoethe. 2010. Performance and amino acid utilization of early lactation dairy cows fed regular or reduced-fat dried distillers grains with solubles. J. Dairy Sci. 93:3176-3191.

Næs, T., P. B. Brockhoff, and O. Tomic. 2010. Statistics for Sensory and Consumer Science. Wiley, John Wiley and Sons Ltd., Chippenham, UK.

Nichols, J. R., D. J. Schingoethe, H. A. Maiga, M. J. Brouk, and M. S. Piepenbrink. 1998. Evaluation of corn distillers grains and ruminally protected lysine and methionine for lactating dairy cows. J. Dairy Sci. 81:482-491.

Oba, M., G. B. Penner, T. D. Whyte, and K. Wierenga. 2010. Effects of feeding triticale dried distillers grains plus solubles as a nitrogen source on productivity of lactating dairy cows. J. Dairy Sci. 93:2044-2052.

Ouellet, D. R., and J. Chiquette. 2016. Effect of dietary metabolizable protein level and live yeasts on ruminal fermentation and nitrogen utilization in lactating dairy cows on a high red clover silage diet. Anim. Feed Sci. Technol. 220:73-82.

Overton, T. R., M. R. Cameron, J. P. Elliot, J. H. Clark, and D. R. Nelson. 1995. Ruminal fermentation and passage of nutrients to the duodenum of lactating cows fed mixtures of corn and barley. J. Dairy Sci. 78:1981-1998.

Pariza, M. W., Y. Park, and M. E. Cook. 2001. The biologically active isomers of conjugated linoleic acid. Prog. Lipid Res. 40:283-298.

Parodi, P. W. 2009. Has the association between saturated fatty acids, serum cholesterol and coronary heart disease been over emphasized? Int. Dairy J. 19:345-361.

Pedersen, M. B., S. Dalsgaard, K. E. B. Knudsen, S. Yu, and H. N. Lærke. 2014. Compositional profile and variation of distillers dried grains with solubles from various origins with focus on non-starch polysaccharides. Anim. Feed Sci. Technol. 197:130-141.

Reyes Sánchez, N., E. Spörndly, and I. Ledin. 2006. Effect of feeding different levels of foliage of Moringa oleifera to creole dairy cows on intake, digestibility, milk production and composition. Livest. Sci. 101:24-31.

Roche, H. M., E. Noone, C. Sewter, S. Mc Bennett, D. Savage, M. J. Gibney, S. O'Rahilly, and A. J. Vidal-Puig. 2002. Isomer-dependent metabolic effects of conjugated linoleic acid: Insights from molecular markers sterol regulatory element-binding protein-1c and LXRalpha. Diabetes 51:2037-2044.

Rudemo, M., S. Bech-Andersen, and V. Mason. 1980. Hydrolysate preparation for amino acid determinations in feed constituents. Z Tierphysiol. Tierernahr. Futtermittelkd. 43:27-34.

Schingoethe, D. J., M. J. Brouk, and C. P. Birkelo. 1999. Milk production and composition from cows fed wet corn distillers grains. J. Dairy Sci. 82:574-580

Sjaunja, L. O., L. Baevre, L. Junkkarinen, J. Pedersen, and J. Setala. 1991. A Nordic proposal for an energy corrected milk (ECM) formula EAAP Publication 50. Pages 156-157 in Performance Recording of Animals - State of the Art 1990. InCentre for Agricultural Publishing and Documentation (PUDOC), Wageningen, the Netherlands.

Stoldt, W. 1952. Vorslag zur vereinheitlichung der fettbestimmung in lebensmitteln. Fette Seifen 54:206-207. (Suggestion to standardize the determination of fat content in foods).

Testroet, E. D., G. Li, D. C. Beitz, and S. Clark. 2015. Feeding dried distillers grains with solubles affects composition but not oxidative stability of milk. J. Dairy Sci. 98:2908-2919.

Tilley, J. M., and R. A. Terry. 1963. A two stage technique for the in vitro digestion of forage crops. J. Br. Grassl. Soc. 18:104-111. 
Timmons, J. S., W. P. Weiss, D. L. Palmquist, and W. J. Harper. 2001. Relationships among dietary roasted soybeans, milk components, and spontaneous oxidized flavor of milk. J. Dairy Sci. 84:2440-2449.

Van Soest, P. J. 1963. Use of detergents in the analysis of fibrous feed. 2) A rapid method for the determination of fiber and lignin. J. Assoc. Off. Agric. Chem. 46:829-835.

Volden, H. 2011. NorFor-The Nordic feed evaluation system. EAAP Publications No 130. Wageningen Academic Publishers, Wageningen, the Netherlands.

Weisbjerg, M., and T. Hvelplund. 1993. Bestemmelse af nettoenergiindhold (FEk) i foder til kvæg. Research Report No. 3, Statens Husdyrbrugsforsøg, Foulum. Research Centre Foulum, Aarhus University, Tjele, Denmark.

Weisbjerg, M. R., N. B. Kristensen, T. Hvelplund, P. Lund, and P. Løvendahl. 2010. Malkekoens produktion ved reduceret kvælstoftildeling [The production of the dairy cow at reduced $\mathrm{N}$ allocation]. Pages 17-29 in Malkekoens biologiske potentiale for reduceret udskillelse af fosfor, kvælstof og metan [The Biological Potential of the Dairy Cow to Reduce Emission of Phosphor, Nitrogen and Methane]. N. B. Kristensen, ed. Husdyrbrug nr. 22, maj 2010.
Det Jordbrugsvidenskabelige Fakultet, Aarhus University, Tjele, Denmark.

Weisbjerg, M. R., N. B. Kristensen, T. Hvelplund, P. Lund, and P. Løvendahl. 2012. Feed intake and milk yield responses to reduced protein supply. Page 113 in Book of Abstracts, EAAP Conf. 2012 Wageningen Academic Publishers, Wageningen, the Netherlands.

Whigham, L. D., A. C. Watras, and D. A. Schoeller. 2007. Efficacy of conjugated linoleic acid for reducing fat mass: A meta-analysis in humans. Am. J. Clin. Nutr. 85:1203-1211.

Whitney, M. H., and G. C. Shurson. 2004. Growth performance of nursery pigs fed diets containing increasing levels of corn distillers dried grains with solubles originating from a modern Midwestern ethanol plant. J. Anim. Sci. 82:122-128.

Wohlt, J. E., C. J. Sniffen, and W. H. Hoover. 1973. Measurement of protein solubility in common feedstuffs. J. Dairy Sci. 56:1052-1057.

Yildiz, E., and N. Todorov. 2014. The comparison of the main protein sources for dairy cows. A review. Bulg. J. Agric. Sci. 20:428-446.

Zijlstra, R. T., and E. Beltranena. 2009. Variability of quality in biofuel co-products. Pages 313-326 in Recent Advances in Animal Nutrition- 2008. P. C. Gamesworthy and J. Wiseman, ed. Nottingham University Press, Nottingham, UK. 